\title{
INFLUENCE OF WOOD CHIP QUALITY ON BOILER HOUSE EFFICIENCY
}

\author{
Agate Klavina, Raimunds Selegovskis \\ Latvia University of Life Sciences and Technologies, Latvia \\ amanda.klavina@inbox.lv, raimunds.selegovskis@1lu.lv
}

\begin{abstract}
Wood chips that are used as a fuel for biomass boiler houses in Latvia are mainly obtained from logging, therefore, their quality and content are very variable. In addition to wood, wood chips may contain sawdust, bark, fir needles, sand, and soil. The quality of wood chips is determined by its composition. For the best biomass boiler efficiency, the fuel moisture is determined not to exceed 50\% and ash content not to exceed 5\%. In practice wood chip composition analysis shows that the moisture content varies from $25 \%$ to $58 \%$, while the content of ash varies from $2.5 \%$ to $5.2 \%$. High moisture content in wood chips decreases the fuel net calorific value more than high ash content. It should be noted that higher ash content and moisture increase the boiler house operating costs, because the efficiency decreases that can result as an increase of the heat energy trade price. Using a flue gas condenser, there is a possibility to recover some heat losses caused by leaving water vapor in the flue gas, but anyway, the moisture decreases the efficiency of burning. The heat production efficiency of 3.1 MW wood chip boiler used for centralized district heating and hot water producing is determined using existing statistics data and measurements and evaluated taking into account the boiler operating capacity, produced heat energy, amount of wood chips used for firing and fuel quality parameters, such as moisture and ash content, calorific value. The influence of the wood chip composition on the boiler house efficiency is studied. The boiler house operation was monitored since 16th November 2020 till 21st January 2021. The monitored period was divided in 5 shorter periods to be able to compare the heat generation system efficiency under the influence of various wood chip parameters. The results showed that the specific boiler house efficiency was the lowest $(70 \%)$ in the period, when the ash content of the fuel was high (average 5.30\%), the moisture level was low (average 24.30\%). The highest efficiency (94\%) was identified, when the average ash content was $3.2 \%$ and the average moisture content $47.68 \%$.
\end{abstract}

Keywords: wood chips, fuel quality, biomass boiler, energy effieciency, boiler operation.

\section{Introduction}

In Latvia, as in Lithuania and other European countries with cold climates, district heating systems are well developed [1]. Most of the biomass used for the energy sector in the EU is wood [2]. Wood biomass from forests consists mainly of by-products of forest management [3]. Wood chips are type of solid wood-based biofuel [4]. Latvian municipalities, where wood chip fired biomass boiler houses are built as central heating system heat generation plants, purchase wood chips, paying for the energy value in MWh or for the chip volume in $\mathrm{m}^{3}$ (if it is not possible to weigh the wood chips cargo in the territory of the power plant). To determine the energy capacity of each load, wood chip samples are taken and tested in a certified laboratory. Fuel must be of high quality to be burned in grate combustion technology. However, increased quality requirements also increase the price of fuel. To stay competitive, heat producers utilise biofuel of lower quality with the moisture content up to $60 \%$. As the drying process occupies most of the space in the boiler furnace, combustion on the grate of such biofuel is complicated [5]. Ignition and combustion problems can appear due to high fuel moisture and ash contents. If the melting point of ash is low, fouling, clinkering, melting and slagging problems can appear [6;7]. Investigations show that these problems can also be caused by low viscosity of melts and components of $\mathrm{K}, \mathrm{NA}, \mathrm{Cl}, \mathrm{Si}, \mathrm{Ca}, \mathrm{Mg}, \mathrm{P}$ and $\mathrm{Fe}$ in fuel, also particle impaction - sticking, thermophoresis, condensation and chemical reactions [7]. The ash content of woodchips is significantly influenced by the origin. Ash content of forest residues can be higher compared to that of energy roundwood and often exceeds the requirements of ISO 17225-4 (max. $1.5 \%$ in the A2 class) [8]. The average ash content of wood chips from logging residues is 3-4\% [9]. That is approximately $1-2 \%$ higher than in chips from branches and whole trees. Various studies have described the problems caused by burning of poorquality wood chips. The question remains exactly how poor chip quality affects the efficiency of the boiler. This study provides an assessment of the efficiency of wood chip boiler operation, identifying consequences of poor-quality wood chip burning in the moving grate boiler and its impact on the boiler house efficiency.

\section{Materials and methods}

Specific biomass boiler house in Ozolnieki village, Latvia (56 $41^{\prime} 29.7^{\prime \prime} \mathrm{N} 23^{\circ} 46^{\prime} 03.0$ 'E), with AGRO Forst \& Energietechnik GmbH produced technology AVR 3100 contains a moving grate furnace 
with a capacity of 3.1 MW, hot water boiler, firebox (including fans), walking floor discharge, hydraulic stocker, flue gas equipment, mechanical ash removal and electrical control unit. The heat generation system is installed in 2016 and is fully automatized. Grate-firing is a competitive technology of biomass combustion for heat production thanks to its capability to fire a wide range of fuel with varying moisture content, requiring less fuel preparation and physical work of the operator at the same time [10]. Heat generation capacity directly depends not only on the outdoor temperature, but also on the very volatile village heat demand, as hot water is also prepared for consumers of the central heating system. The wood chips procurement procedure is performed before the heating season (the heating season lasts from October till the end of April). There are specific chip quality parameters determined in contracts with fuel suppliers, for example, the net calorific value $\left(\geq 1.95 \mathrm{MWh} \cdot \mathrm{t}^{-1}\right)$, chip moisture $(\leq 55 \%)$, and the ash content $(\leq 5.0 \%)$. The composition of the fuel was determined - sawdust $(\leq 30 \%)$, wood chips $(\leq 100 \%)$, bark $(\leq 30 \%)$, conifer needles $(\leq 3 \%)$, and sand $(\leq 1 \%)$. Wood chip fired biomass boiler house is used for heat production for Ozolnieki central heating system during the heating season. The chips were purchased from two certain suppliers with a contract for the entire season, but the results of investigations can be generalised, because the aim was to study the impact of the specific chip parameter: the moisture and ash content on the efficiency of the boiler plant. Each wood chip cargo that delivers fuel is weighed on scales (electronic terminal model D400, accuracy 0.05\%) produced by Italian manufacturer (Societa Cooperativa Bilanciai), located in the boiler house territory. A wood chip sample 3 litres is taken from 4 places of each load. Samples are collected and handed to the laboratory once in a two week period. As soon as the laboratory results are ready, it is possible to calculate the energy content of each load. Moisture content is tested for each cargo load; the ash content is tested for all loads of each period and one common ash content value given. In a situation when some wood chip quality parameters are higher as per determined in the contract, the pay factor is applied by the customer to the supplier for higher muisture value (if the moisture content $\geq 55.1 \%$, the pay factor 0.8 is applied; if the moisture content $\geq 57.6 \%$, the pay factor 0.7 is applied) and ash content (if the ash content $\geq 5.1 \%$, the pay factor 0.8 ; if the ash content $\geq 6.1 \%$, the pay factor is 0.7 ).

According to the laboratory results, the wood chip gross calorific value at constant volume is calculated using formula (1):

$$
q_{V, g r}=\frac{\varepsilon_{(n)} \times \theta-Q_{f u s e}-Q_{i g n}-Q_{N}}{m}-\frac{Q_{S}}{m},
$$

where $q_{V, g r}$ - gross calorific value at constant volume of the analysed fuel, $\mathrm{J} \cdot \mathrm{kg}^{-1}$;

$\varepsilon(n)$ - value of the effective heat capacity of the calorimeter (determined experimentally for each calorimeter) $\mathrm{J} \mathrm{K}^{-1}$;

$\theta$ - corrected temperature rise, $\mathrm{K}$;

$Q_{\text {fuse }}$ - heat from combustion of the fuse, J;

$Q_{i g n}$ - heat from oxidation of the ignition wire, J;

$Q_{N}$ - heat from formation of nitric oxide, J;

$Q_{S}$ - correction for taking sulfur from the aqueous sulphuric acid to gaseous sulfur dioxide, $\mathrm{J}$;

$m$ - mass of the sample of the fuel, $\mathrm{g}$.

In view of the results obtained, the gross calorific value of the dry fuel (dry basis in dry matter) is determined (formula (2)):

$$
q_{V, g r, d}=q_{V, g r} \times \frac{100}{100-M_{a d}},
$$

where $\quad q_{V, g r, d}-$ gross clorific value at constant volume of moisture free fuel, $\mathrm{J} \cdot \mathrm{kg}^{-1}$;

$M_{a d}$ - moisture content in the sample, $\%$.

The net calorific value at constant pressure of a dry sample basis in dry matter is calculated (formula (3)) [11]:

$$
q_{p, n e t, d}=q_{V, g r, d}+212.2 \times w(\mathrm{H})_{d}-0.8 \times\left[w(\mathrm{O})_{d}+w(\mathrm{~N})_{d}\right],
$$

where $w(\mathrm{H})_{d}$ - content of hydrogen in moisture-free fuel sample, \%; 
$w(\mathrm{O})_{d}$ - content of oxygen in moisture-free fuel sample, $\%$

$w(\mathrm{~N})_{d}$ - content of nitrogen in moisture-free fuel sample, $\%$. (4)):

Net calorific value at constant pressure for each sample moisture content is calculated (formula

$$
q_{p, n e t, m}=q_{p, n e t, d} \times(1-0.1 M)-24.43 M
$$

where $\quad M-$ content of moisture in the specific sample, $\%$.

By multiplying the mass of each wood chip cargo load by the resulting calorific value, the actual energy content of the wood chips is determined. Collecting data from a heat meter of the biomass boiler house output, the system efficiency was calculated for each of the 5 periods.

Quantity of wood chips in tons delivered in each period was summarized (Table 1).

Amount and composition of wood chips fired in various periods

Table 1

\begin{tabular}{|c|c|c|c|c|c|c|c|c|c|}
\hline \multirow[b]{2}{*}{$\begin{array}{c}\text { Period } \\
\text { No. }\end{array}$} & \multicolumn{2}{|c|}{ Period } & \multicolumn{5}{|c|}{ Burned } & \multirow{2}{*}{$\begin{array}{c}\text { Produced } \\
\text { Heat, } \\
\text { MWh }\end{array}$} & \multirow[b]{2}{*}{$\begin{array}{c}\text { Efficiency, } \\
\%\end{array}$} \\
\hline & From & Till & $\begin{array}{l}\text { Amount } \\
\text { of } \\
\text { chips, t }\end{array}$ & $\begin{array}{c}\text { Moisture } \\
\text { content, } \\
\%\end{array}$ & $\begin{array}{c}\text { Ash } \\
\text { content, } \\
\%\end{array}$ & $\begin{array}{l}\text { Calorific } \\
\text { value, } \\
\text { MWh } \mathrm{t}^{-1}\end{array}$ & $\begin{array}{c}\text { Heat } \\
\text { amount, } \\
\text { MWh }\end{array}$ & & \\
\hline $1^{\text {st }}$ & $\begin{array}{c}16 \\
\text { Nov } \\
2020\end{array}$ & $\begin{array}{c}29 \\
\text { Nov } \\
2020\end{array}$ & 174.56 & 50.57 & 2.60 & 2.735 & 477.384 & 433.531 & 91 \\
\hline $2^{\text {nd }}$ & $\begin{array}{c}30 \\
\text { Nov } \\
2020\end{array}$ & $\begin{array}{c}13 \\
\text { Dec } \\
2020\end{array}$ & 208.26 & 37.19 & 3.80 & 2.904 & 604.861 & 493.149 & 82 \\
\hline $3^{\text {rd }}$ & $\begin{array}{c}14 \\
\text { Dec } \\
2020\end{array}$ & $\begin{array}{c}03 \\
\text { Jan } \\
2021\end{array}$ & 314.62 & 31.53 & 3.05 & 3.379 & 1062.990 & 748.673 & 70 \\
\hline $4^{\text {th }}$ & $\begin{array}{c}4 \\
\text { Jan } \\
2021 \\
\end{array}$ & $\begin{array}{c}17 \\
\text { Jan } \\
2021 \\
\end{array}$ & 291.44 & 43.37 & 1.30 & 2.620 & 763.534 & 627.103 & 82 \\
\hline $5^{\text {th }}$ & $\begin{array}{c}18 \\
\text { Jan } \\
2021 \\
\end{array}$ & $\begin{array}{c}31 \\
\text { Jan } \\
2021 \\
\end{array}$ & 224.46 & 47.68 & 3.20 & 2.337 & 524.456 & 492.888 & 94 \\
\hline
\end{tabular}

\section{Results and discussion}

When evaluating the summarized data from all 5 periods, the wood chip moisture content varies from $31.53 \%$ to $50.57 \%$, which is close to other similar studies where moisture content in winter months varies from $42 \%$ to $46 \%$ [12] in average range from $40 \%$ to $50 \%$ [13].

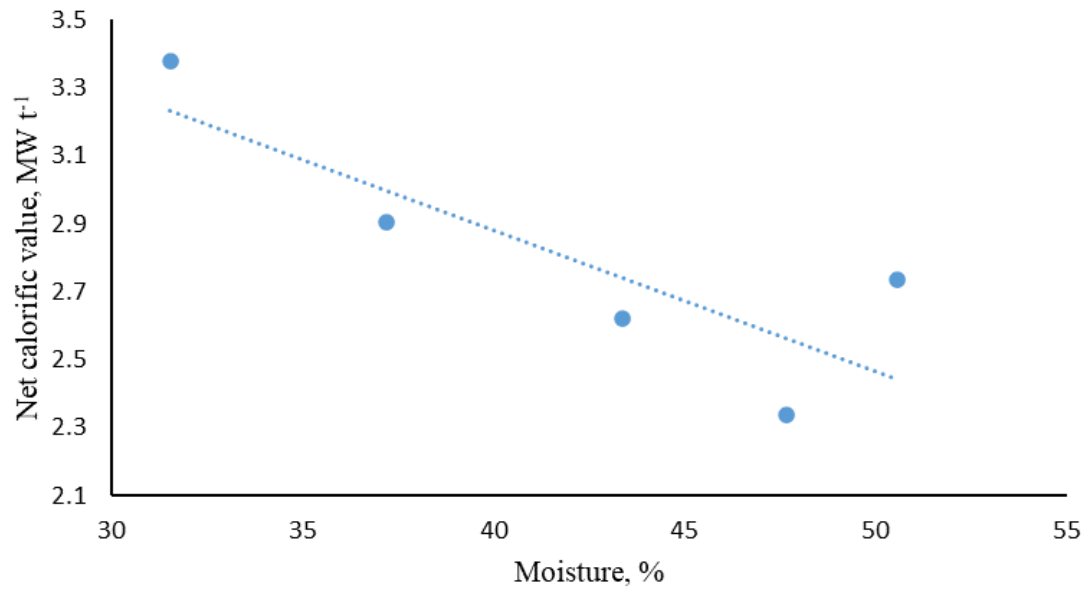

Fig. 1. Correlation between wood chip moisture and net calorific value 
It is observed that the efficiency of the boiler house increases if fuel moisture level is higher. This is a phenomenon because the moisture level significantly affects the calorific value of the wood chips (Fig. 1).

The lower the humidity, the higher the energy value of the fuel [11]. With an increase in moisture, the net calorific value is reduced proportionally [4].

That means, there are other very important factors that more significantly affect the efficiency of the boiler. Under normal boiler operation conditions, the fuel with higher moisture content should decrease the boiler efficiency, as it is naturally more beneficial to burn a dry material [4]. The question is why in the specific situation the results show the opposite.

To gain a deeper understanding of exactly which chip parameters affect the operation of the boiler negatively, in-depth research of wood chip and boiler house parameters was carried out for the $3^{\text {rd }}$ period (14 Dec 2020 to 17 Jan 2021). The power output graph shows 21 extreme power drops that means an emergency stop of the boiler operation (see Fig. 2).

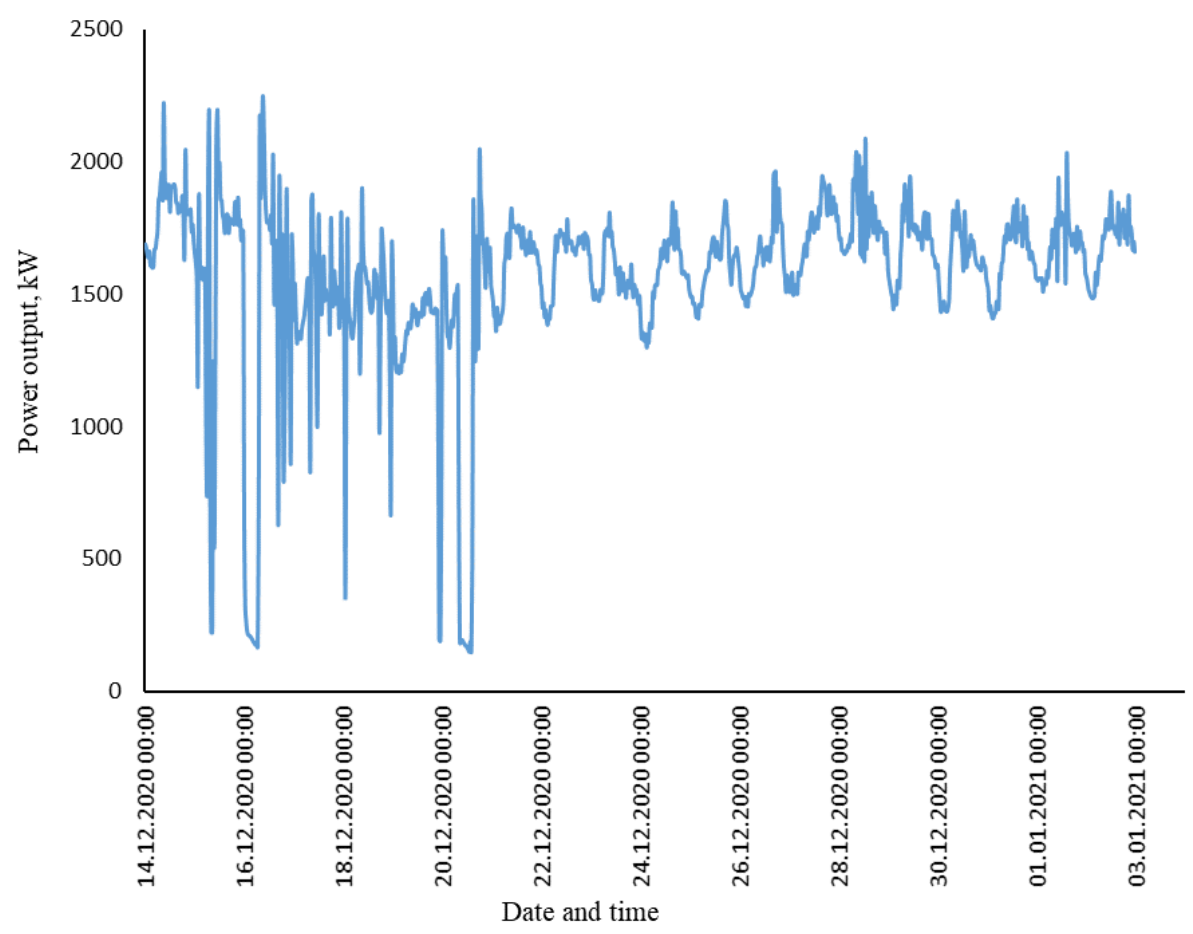

Fig. 2. Biomass boiler house output power, $\mathrm{kW}$

There is one electrical connection defect detected in the boiler house operational log during the $3^{\text {rd }}$ period, the rest 20 emergency stops have occurred due to large ash formation on the combustion surface (see Figure 3). Large formations cannot fall through the boiler moving grate surface and create congestion that interferes the operation of the sensors located in the boiler firebox. In such case, the moving grate furnace has to be cleaned from ash manually.

To determine the cause of the problem, two wood chip samples received on $14^{\text {th }}$ December, 2020 were resent for analysis. The results of the analyzes are shown in Table 2. Net calorific values for both samples were relatively high, moisture was low, however, the ash content exceeded the specified value of the agreement.

Table 2

Wood chip parameters during boiler operation at low efficiency

\begin{tabular}{|c|c|c|c|}
\hline $\begin{array}{l}\text { Delivery } \\
\text { date }\end{array}$ & $\begin{array}{c}\text { Ash content, } \\
\%\end{array}$ & $\begin{array}{c}\text { Moisture } \\
\text { content, \% }\end{array}$ & 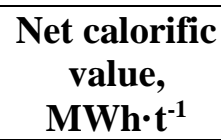 \\
\hline $14 \operatorname{Dec} 2020$ & 5.30 & 24.30 & 3.608 \\
\hline
\end{tabular}




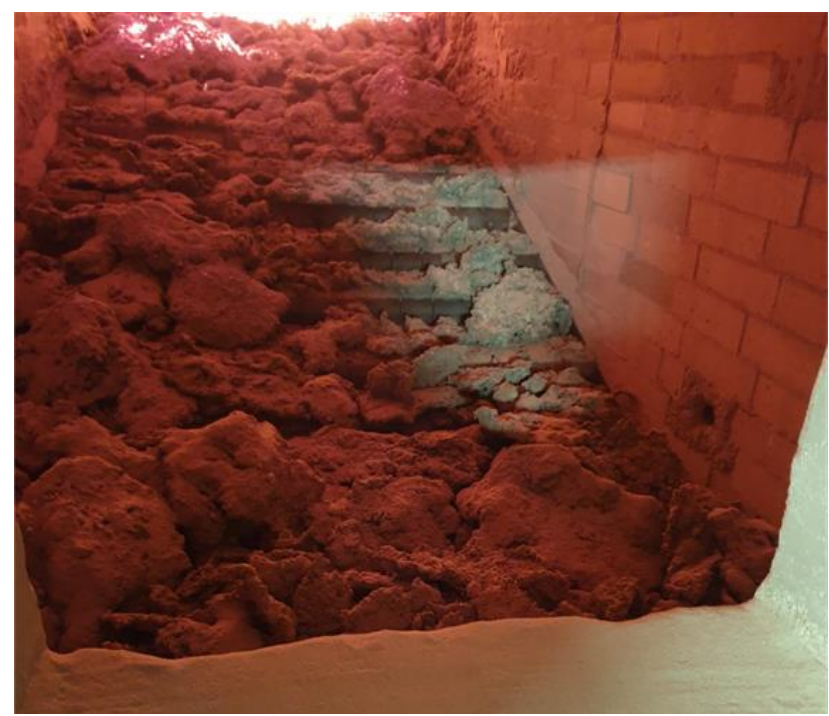

Fig. 3. Boiler moving grate surface during emergency stop

The performed research shows that to ensure efficient operation of Ozolnieki village central boiler house it is important to avoid burning wood chips with a high ash content. If excluding the $3^{\text {rd }}$ period efficiency result from average efficiency calculating, the boiler house system efficiency is $87 \%$. If the high ash content fuel is used in combustion, there is a risk of reducing the efficiency of the system by $17 \%$ due to emergency stops for cleaning and worse heat transfer inside furnace due to ash sludge during longer operation period. The costs of purchased wood chips were compiled concluding that the average price of wood chips during the study was 12.32 EUR per $1 \mathrm{MWh}$. Comparing the cost of wood chips consumed to provide $748.673 \mathrm{MWh}$ heat produced at the $3^{\text {rd }}$ period at different boiler house efficiencies, it was found that efficiency drop from $87 \%$ to $70 \%$ can lead to $24 \%$ cost increase for fuel consumption (see Fig. 4).

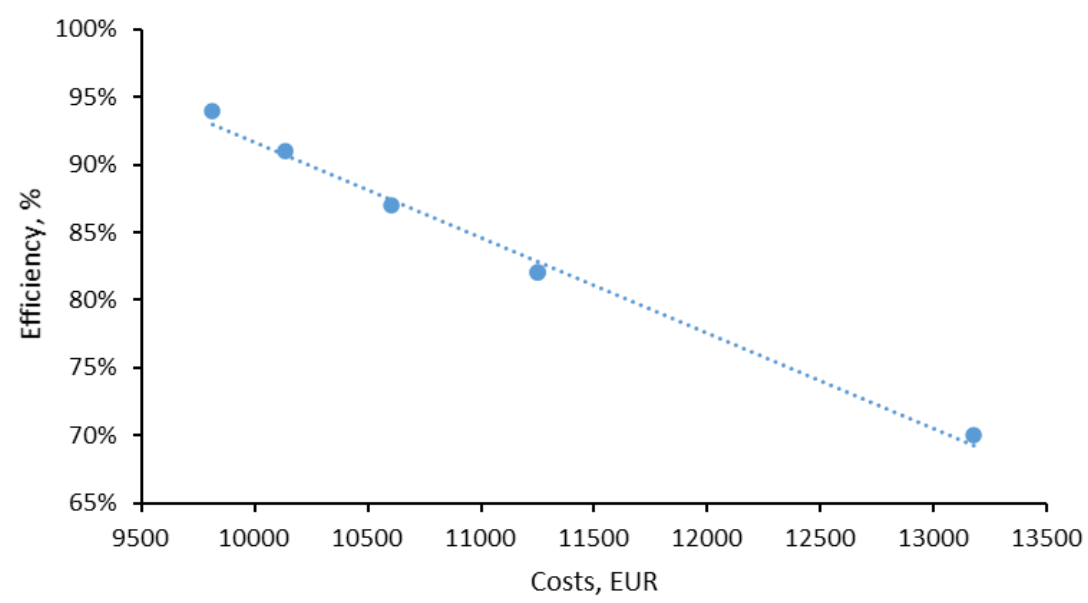

Fig. 4. Fuel consumption costs at different boiler house efficiencies

Thus, the ash content is a very important factor influencing the efficiency of the boiler. If losses caused by moisture can be recovered very efficiently by using flue gas condensation and lowering the exhaust gas temperature [14], then specific preventive technical solutions are needed for ash. Approximate moisture of the wood chip cargo can be easily tested before combustion using a humidity meter. If there is no option to test the fuel ash content in the laboratory before combustion, visual inspection of the wood chip cargo delivered is important even if it is a subjective method and the factor of human error is possible.

\section{Conclusions}

1. Wood chip parameters affect combustion and ash sludge formation in the boiler. High moisture content decreases the net calorific value of the wood chips. However, this study shows that using 
dry fuel with high ash content results to ash formation problems and make the operation of the equipment complicated. That accordingly can lead to $17 \%$ decrease of the boiler house system overall operating efficiency and $24 \%$ increase of the heat production cost.

2. Analyzing the boiler operation statistics, it is concluded that overall boiler house efficiency is significantly affected by emergency stops for cleaning of ash deposits and prevention of operation accidents. During the period with the lowest efficiency (70\%), there were 20 boiler shutdowns and subsequent start-up periods due to large ash formation on the combustion surface.

3. In order to improve the efficiency of the central boiler house operation, an in-depth research should be carried out to evaluate the decrease of the boiler house system efficiency not only under the influence of the chip parameters, but also in the operating parameters of the equipment. Such a study would provide an opportunity to assess the options for improving the performance of the system and the prevent boiler house malfunctions.

\section{References}

[1] Jonynas R., Puida E., Poškas R., etc. Renewables for district heating: The case of Lithuania, Energie, vol. 211, 2020, 119064.

[2] Díaz-Yáñez O., Mola-Yudego B., Anttila P., etc. Forest chips for energy in Europe: Current procurement methods and potentials. Renewable and Sustainable Energy Reviews, vol. 21, 2013, pp. 562-571.

[3] Mola-Yudego B., Arevalo J, Díaz-Yáñez O., etc. Wood biomass potentials for energy in northern Europe: Forest or plantations? Biomass and Bioenergy, vol. 106, 2017, pp. 95-103.

[4] Moskalik T., Gendek A. Production of Chips from Logging Residues and Their Quality for Energy: A Review of European Literature. Forests, 2019, 10, 262.

[5] Vorotinskienè L. Parameters affecting biomass during combustion in moving grate furnaces. Energetika, vol. 65, 2019, pp. 71-84.

[6] Demirbas A. Combustion characteristics of different biomass fuels. Progress in Energy and Combustion Science, vol. 30, 2004, pp. 219-230.

[7] Vassilev S.V., Baxter D., Andersen L. K., etc. An overview of the composition and application of biomass ash: Part 2. Potential utilisation, technological and ecological advantages and challenges. Fuel, vol. 105, 2013, pp.19-39.

[8] Zanetti M., Costa C., Greco R., etc. How Wood Fuels' Quality Relates to the Standards: A ClassModelling Approach. Energies, 2017,10, 1455.

[9] Gendek A., Nurek T. Variability of energy woodchips and their economic effects. Folia For. Pol. Ser. A - Forestry, 2016, 58(2), 62-71. [online] [08.02.2021] Available at: https://content.sciendo.com/view/journals/ffp/58/2/article-p62.xml?language = en

[10] Yin Ch., Rosendahl L.A., Kær S.K. Grate-firing of biomass for heat and power production. Progress in Energy and Combustion Science, vol. 34, 2008, pp. 725-754.

[11] LVS EN ISO 18125:2017 standard "Solid biofuels - Determination of calorific value"

[12] Gendek A., Nurek T., etc. Effects of Intentional Reduction in Moisture Content of Forest Wood Chips during Transport on Truckload Price. BioResources, vol. 13, 2018, pp. 4310-4322.

[13] Laitila, J.; Ahtikoski, A.; Repola, J.; etc. Pre-feasibility study of supply systems based on artificial drying of delimbed stem forest chips. Silva Fenn. 2017, 51, 5659.

[14] Visockis E., Vucenlazdans P., Selegovskis R. Innovative Flue Gas Heat Absorbtion System For Buildings With Biomas Fired Boiler. Proceedings of 12th International Scientific Conference on Engineering for Rural Development. Jelgava, 2013. pp. 376-381. 